\title{
Epigallocatechin gallate inhibits the growth of salivary adenoid cystic carcinoma cells via the EGFR/Erk signal transduction pathway and the mitochondria apoptosis pathway
}

\author{
L. X. WENG, G. H. WANG, H. YAO, M. F. YU, J. LIN* \\ Department of Stomatology, the First Affiliated Hospital, School of Medicine, Zhejiang University, 79, Qingchun Road, Hangzhou Zhejiang, \\ 310000 People's Republic of China \\ *Correspondence: linjunzdyy@163.com
}

Received October 8, 2016 / Accepted January 19, 2017

\begin{abstract}
ACC is one of the most malignant tumors in salivary gland, and of poor prognosis. A critical role in ACC development and progression is played by EGFR family members including EGFR. EGCG, a low molecular weight polyphenol contained in green tea, has broad anticancer properties, but whether EGCG regulates activity of ACC is unknown. In the present study, the effects of EGCG were investigated in vitro with particular attention to the pathway of EGFR/Erk and mitochondria apoptosis in SACC-83 cell lines. The results of MTS assay and flow cytometry demonstrated that EGCG $(20-80 \mu \mathrm{M})$ could inhibit proliferation and promote apoptosis of SACC-83 cells. Furthermore, by Western blotting with antibodies specific for EGFR, Erk 1/2 (p-Erk 1/2), Mek (p-Mek), Bcl-2, and Bax, it was demonstrated that EGCG could reduce the expression of EGFR, inhibit phosphorylation of Erk 1/2 and Mek, downregulate Bcl-2, and upregulate Bax. In addition, it was also shown that EGCG could inhibit mRNA expression of P90 RSK by RT-PCR. In conclusion, the results suggest that EGCG might be a potential therapeutic or adjuvant strategy for the treatment of patients with ACC, by inhibiting proliferation and inducing the apoptosis of the tumor cells.
\end{abstract}

Key words: EGCG, ACC, EGFR, MAPK, Bcl-2

ACC is one of the most malignant tumors in salivary gland and the predominant histologic type among malignancies of the minor salivary glands and the submandibular gland [1]. Although it grows slowly, it is strongly invasive. It often grows along nerves and blood vessels and tends to recur and metastasize $[2,3]$. Studies have reported that the long-term disease control is poor in spite of a good 5-year survival rate [4]. H. Kokemueller et al. reported that survival rates of ACC at 5, 10 and 15 years were $71 \%, 54 \%$ and $37 \%$ with a mean overall survival of 11.2 years [5]. Nowadays ACC is mainly treated with wide tumor-free surgical margin excision and radiation, or chemoradiotherapy $[6,7]$. However these treatments are not ideal with poor prognosis. Because of the strong aggression of its character and the particular anatomy of oral and maxillofacial region, surgery may not be the best approach. Choice of enlargement resection and removing all the adjacent peripheral nerves result in sacrificing the facial nerves or other critical structures or organs. And if the nerves nearby are preserved, tumor tends to recur after surgery. ACC has a high recurrence rate, with 5-year recurrence rates of $35 \%$ to $50 \%$ [8]. For preventing recurrence and metastasis, post-operative modalities including radiotherapy and chemotherapy should be implemented. Though the curative effect of conventional chemotherapy should be affirmed, its side effects and the drug resistance of tumor cells are still hard problems in clinic [9]. Researching a non-toxic method which can inhibit tumor cell growth would be a better strategy.

Tea polyphenols has a good anti-tumor activity in animal models and humans [10]. EGCG is the most abundant and active phenolic constituent of tea polyphenols and has strong antioxidant properties, possessing chemotherapeutic and chemopreventive roles [11, 12]. Previous studies showed that EGCG can inhibit the growth and metastasis of oral cancer, breast cancer, hepatic cancer, colorectal cancer and other cancer cells [13-16] via a variety of ways. Many anticancer mechanisms of EGCG have been mentioned such as antioxidant activity, cell cycle stationary, induction of apoptosis, inhibition of DNA methylation, and effect on small RNA, 
protease, telomerase, dihydrofolate reductase and regulation of cell signaling pathways [17-19].

EGCG could inhibit receptors in cell membrane such as EGFR [20, 21], HGFR [22], VEGFR [23], and action sites in cells such as MMPs [24, 25], P90 RSK [21], Bcl-2 family [26], and Erk, P38 MAPK, JNK, Akt which belong to MAPK family [21]. These action sites and others that have not been found or confirmed form a complicated signal transduction network, by which EGCG affects biological behaviors of tumor cells including proliferation, apoptosis, invasion and metastasis.

In the present study, the effects of EGCG were investigated in SACC-83 cell lines. MTS assay and flow cytometry were performed to evaluate the effect of EGCG on proliferation and apoptosis. The protein expression levels of the pathway of EGFR/Erk and mitochondria apoptosis-related Bcl-2, Bax were evaluated using Western blotting analysis and the mRNA levels of P90 RSK was measured by RT-PCR.

\section{Materials and methods}

Cell culture. The human salivary gland adenoid cystic carcinoma cell line, SACC-83, was a gift from the College of Stomatology, Beijing University, which was cultured in PRMI 1640 media (PAA LaboratoriesGmbH, AUS), supplemented with $10 \%$ fetal bovine serum (GIBCO, USA), 1\% antibiotic solution containing 10,000 units/mL penicillin and $10000 \mu \mathrm{g} /$ $\mathrm{mL}$ streptomycin (GIBCO), 1\% sodium pyruvate (GIBCO), and 1\% MEM non-essential amino acids (GIBCO). All cells were grown in a humid atmosphere of $5 \% \mathrm{CO}_{2}$, at $37^{\circ} \mathrm{C}$.

Cell proliferation analysis. SACC- 83 cells were seeded in 96-well plates (5000 cells/well) and cultured overnight, then treated with $0,5,10,20,40,80 \mu \mathrm{M}$ EGCG (Sigma-Aldrich, USA). Cell proliferation was evaluated after $24 \mathrm{~h}, 48 \mathrm{~h}$, and $72 \mathrm{~h}$ respectively using the MTS reagent (Promega, USA).

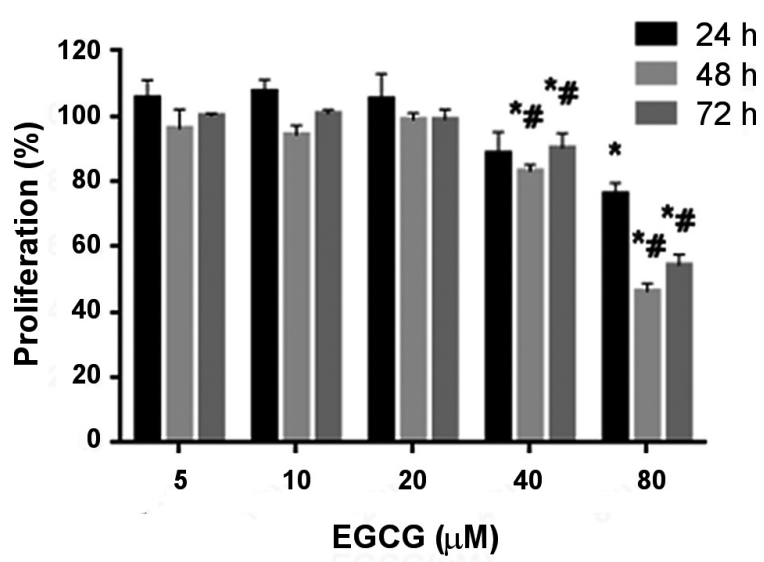

Figure 1. Effect of EGCG on the proliferation of SACC-83 cells. Notes: Cells were treated with EGCG $(0-80 \mu \mathrm{M})$ for $24 \mathrm{~h}, 48 \mathrm{~h}$ or $72 \mathrm{~h}$, and proliferation was assessed by MTS assay. Data were normalized with control (EGCG 0 ) and given by percentage (means $\pm S D, n=3$ ). Significant difference from the control was determined by ANOVA at $\mathrm{P}<0.05$ (denoted as ${ }^{\star}$ ) and from the lower concentration group at $\mathrm{P}<0.05$ (denoted as \#).
Absorbance was detected at $490 \mathrm{~nm}$. Results were normalized with control (EGCG 0) by the formula: cell proliferation rate $=\mathrm{OD}_{\text {test }} / \mathrm{OD}_{\text {ctrl }} \times 100 \%$.

Cell apoptosis analysis. The effect of EGCG on cell apoptosis was determined by flow cytometry after staining the cells with Annexin V-FITC and PI (Annexin V/PI apoptosis kit, BD Biosciences, USA). SACC-83 was seeded in 6-well plates ( $2 \times 10^{5}$ cells/well) overnight, and then treated with desired concentrations of EGCG. Both the floating and adherent cells were collected using $0.25 \%$ trypsin (Gibco) after $24 \mathrm{~h}$, $48 \mathrm{~h}$, and $72 \mathrm{~h}$ respectively. (1 5) $\times 10^{5}$ cells were collected and stained with Annexin-V-FITC solution and PI. Then the cells were evaluated on flow cytometer (Becton Dickinson, Mountain View, CA).

Western blotting. Cell cultures were prepared in the same way as described previously in apoptosis analysis. After treated with a certain concentration of EGCG for $48 \mathrm{~h}$, cells were lysed to extract proteins, and the total proteins were quantified by the BCA method. The sample proteins were separated by electrophoresis on SDS-polyacrylamide gels and transferred onto polyvinylidene difluoride membranes. After blocking, the membranes were incubated with various primary antibodies overnight at $4{ }^{\circ} \mathrm{C}$ and with HRP-linked secondary antibodies for $1 \mathrm{~h}$ at $25^{\circ} \mathrm{C}$. Immunoreactive bands were visualized by chemiluminescent HRP substrate (Millipore Corporation, USA). Optical densities of the band were quantitated by Quantity One software.

RT-PCR. Cell cultures were prepared in the same way as described previously. Total RNA was isolated by Trizol (Life Technologies, UK). Complementary DNA was synthesized by reverse transcription of total RNA using iScript cDNA Synthesis Kit (TaKaRa Bio, Japan). Quantitative RT-PCR was performed using ABI 7900ht system (Applied Biosystems, USA) with iTaq Universal SYBR Green Supermix (Bio-Rad, USA). The GAPDH was used to normalize the expression levels. Relative mRNA expression was calculated using the $\Delta \Delta \mathrm{Ct}$ method. Genes with a fold change of $\leq-1.25$ or $\geq 1.25$ and $\mathrm{P}<0.05$ were considered statistically significant. The primers used were as follows:

\begin{tabular}{|l|l|l|}
\hline Gene & Forward & Reverse \\
\hline GAPDH & $\begin{array}{l}\text { AGAAGGCTGGGGCT- } \\
\text { CATTTG }\end{array}$ & $\begin{array}{l}\text { AGGGGCCATCCACA- } \\
\text { GTCTTC }\end{array}$ \\
\hline P90 RSK & $\begin{array}{l}\text { GAGACTGACTGCT- } \\
\text { GCTCTTGTG }\end{array}$ & $\begin{array}{l}\text { GGTTCCAAAACTGGT- } \\
\text { GACTGAT }\end{array}$ \\
\hline
\end{tabular}

Statistical analysis. All experiments were performed three times. Results were expressed as mean \pm standard deviation (SD). Statistical significance was determined by a one-way analysis of variance (ANOVA). The significance level was set at $\mathrm{P}<0.05$.

\section{Results}

EGCG treatment inhibits proliferation of SACC-83 cells in vitro. An MTS was performed to evaluate the effect of EGCG on the proliferation of SACC-83 cells (Figure 1.) 
EGCG treatment at lower concentrations (0 to $20 \mu \mathrm{M})$ had no significant effect on cell proliferation. But at doses of 40 to $80 \mu \mathrm{M}$, EGCG affected cell proliferation in a dose-dependent manner. After being treated with $40 \mu \mathrm{M}$ EGCG for $48 \mathrm{~h}$ and $72 \mathrm{~h}$, cell viability decreased to $(83.2 \pm 1.8) \%$ and $(90.2 \pm$ $4.3) \%$, respectively (Figure 1). Exposed to $80 \mu \mathrm{M}$ EGCG for $24 \mathrm{~h}, 48 \mathrm{~h}$, and $72 \mathrm{~h}$, cell proliferation reduced to $(76.2 \pm 3.4)$ $\%$, $(46.6 \pm 2.5) \%$, and $(54.4 \pm 3.2) \%$, respectively (Figure 1$)$. After $48 \mathrm{~h}$ and $72 \mathrm{~h}$, cell proliferations of $80 \mu \mathrm{M}$ are lower than that of $40 \mu \mathrm{M}$, and $40 \mu \mathrm{M}$ 's are lower than $20 \mu \mathrm{M}$ 's.

Induction of cell apoptosis. EGCG-induced apoptosis was measured using flow cytometry. Annexin V-FITC/PI assay was used to distinguish apoptotic cells from viable ones. Cells were differentiated to viable (Annexin V-negative and PI-negative), early apoptotic (Annexin V-positive, PI-negative), and late apoptotic (Annexin V-positive and PI-positive) parts. The range of apoptosis was quantified as percentage of Annexin V-positive cells.

Incubation with EGCG at 0 to $10 \mu \mathrm{M}$ scarcely alter the percentage of apoptotic cells, while apoptotic rate was increased after being treated with EGCG at 20 to $80 \mu \mathrm{M}$ compared with control $(\mathrm{P}<0.05)$ (Figure 2). We did not detect the difference among 20 to $80 \mu \mathrm{M}(\mathrm{P}>0.05)$. The results demonstrate higher apoptosis rates in EGCG treatment groups compared with the control group that EGCG induces cell apoptosis significantly at the concentration of 20 to $80 \mu \mathrm{M}$.

Effect of EGCG on protein expression of EGFR/Erk downstream pathways and $\mathrm{Bcl}-2, \mathrm{Bax}$ in SACC-83 cells. To elucidate the molecular mechanisms of EGCG, we examined the protein expression of EGFR and ERK downstream pathways in SACC- 83 cells by Western blotting. As shown in Figure 3 , the level of total EGFR (Cell Signaling, USA) was decreased in a dose-dependent manner after being treated with EGCG $(5-80 \mu \mathrm{M})$ for $48 \mathrm{~h}$ in SACC-83 cells. Additionally, PhosphoErk 1/2 (Thr202/Tyr204, Cell Signaling) and Phospho-Mek (Ser217/221, Cell Signaling) proteins were downregulated by EGCG $(20-80 \mu \mathrm{M})$ after $48 \mathrm{~h}$ without altering the total levels of Erk 1/2 (Cell Signaling) and Mek (Cell Signaling) proteins. Bcl-2 (Epitomics, USA) was inhibited by EGCG. On the contrary, the pro-apoptotic protein Bax (Epitomics) was activated $(\mathrm{P}<0.05)$ by EGCG.

Effect of EGCG on P90 RSK gene expression in SACC-83 cells. To further explore the mechanism of EGCG in SACC-83 cells, we next researched whether P90 RSK expression would be downregulated by EGCG in gene level. The fold change data are presented in Figure 4. As shown in Figure 4, EGCG did not have effect on mRNA levels of P90 RSK gene at small dose (5-10 $\mu \mathrm{M}, \mathrm{P}>0.05)$. While concentration of EGCG increased to $20-80 \mu \mathrm{M}, \mathrm{mRNA}$ levels of P90 RSK gene was distinctively reduced $(\mathrm{P}<0.05)$.

\section{Discussion}

ACC is one of the most malignant tumors of salivary gland, representing about $1 \%$ of all head and neck malignancies
[28] and about $10 \%$ of salivary gland neoplasms [29]. But the prognosis is still poor even the treatment of wide tumor-free surgical margin excision and radiation, or chemoradiotherapy are performed [7] because of tumor character of a locally infiltrative growth along perineural and blood vessel invasion and high rates of local recurrence and distant metastasis[30]. After the operation and radiotherapy, the quality of the life is also influenced seriously.

With the increasing understanding of the molecular biology and the mechanism of head and neck cancer, more and more therapeutic targets have been developed [31]. To search for molecular targets for therapeutic intervention, the importance is to find the biochemical and molecular differences between normal cells and cancer cells. These changes may be associated with the tumor suppressor genes, growth factors and their receptors, tumor angiogenesis factors, protein kinases and so on. Targeted therapies against any of these changes may represent therapeutic targets [32]. However, the characteristics of multiple genes, multiple factors and multiple stages of carcinoma

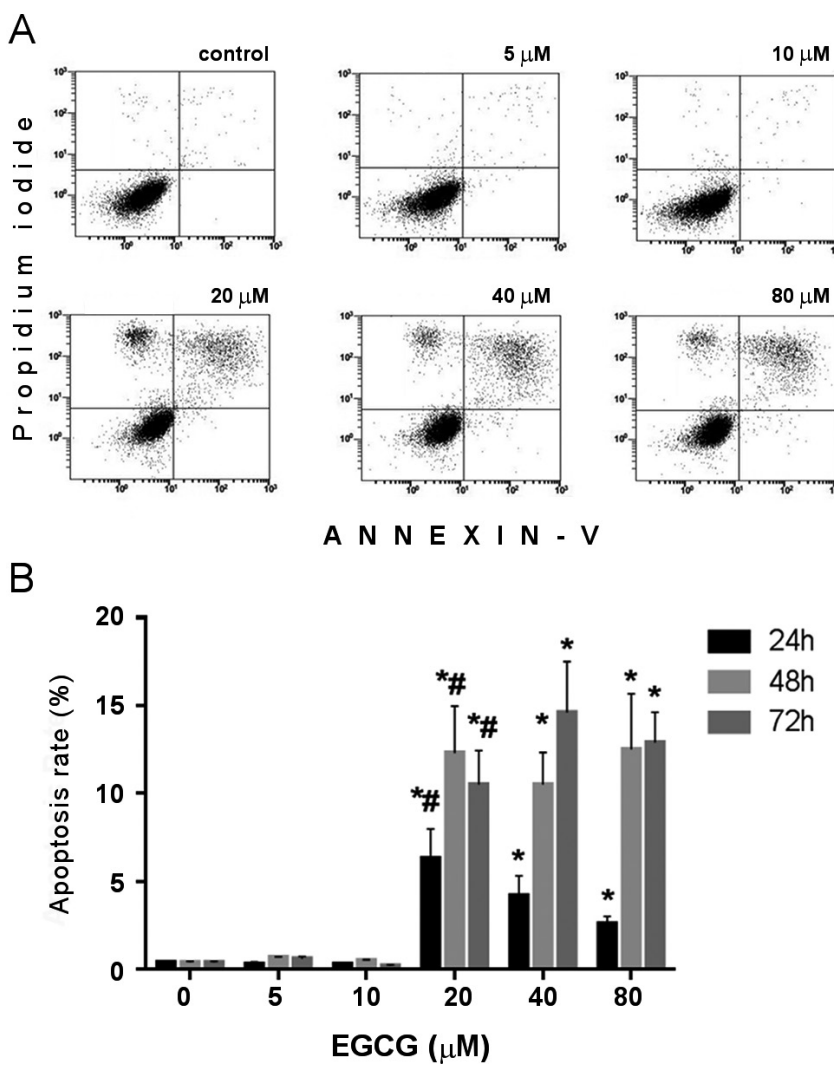

Figure 2. Effect of EGCG on the apoptosis induction of SACC-83 cells. Notes: (A) Dot plot representation of cell viability after being treated with EGCG (0-80 $\mu \mathrm{M})$ for $48 \mathrm{~h}$ by flow cytometry. (B) Apoptosis rate of SACC-83 cells after treated with EGCG $(0-80 \mu \mathrm{M})$. Cells were cultured with EGCG (0-80 $\mu \mathrm{M})$ for 24, 48 and $72 \mathrm{~h}$ and marked with Annexin V-FITC/ PI. Values are shown as means \pm SD of 3 replicates. Significant difference compared with control (EGCG 0$)$ can be found at * $(\mathrm{P}<0.05)$, and with lower concentration group at \# $(\mathrm{P}<\mathbf{0 . 0 5})$. 

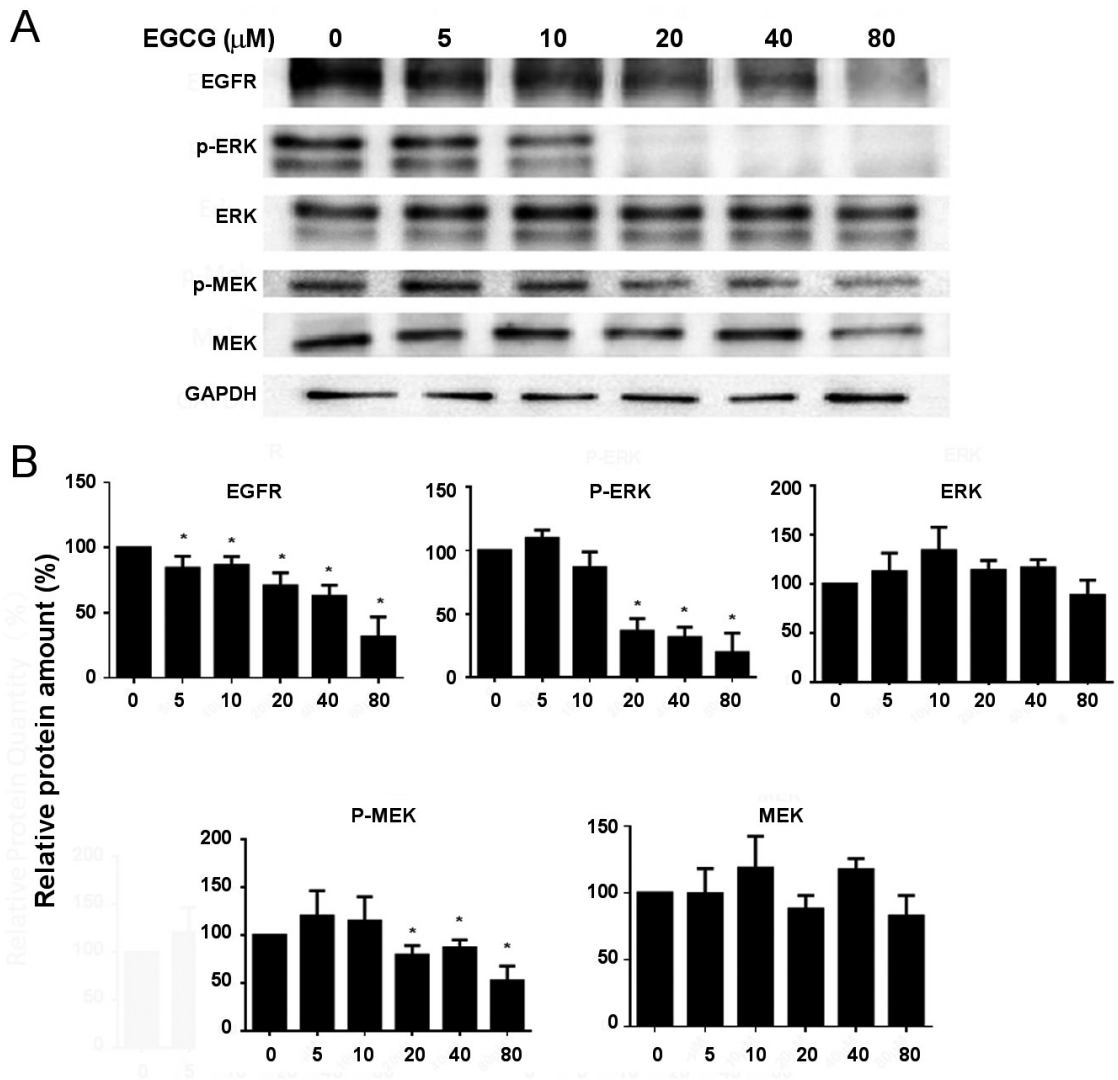

EGCG $(\mu \mathrm{M})$

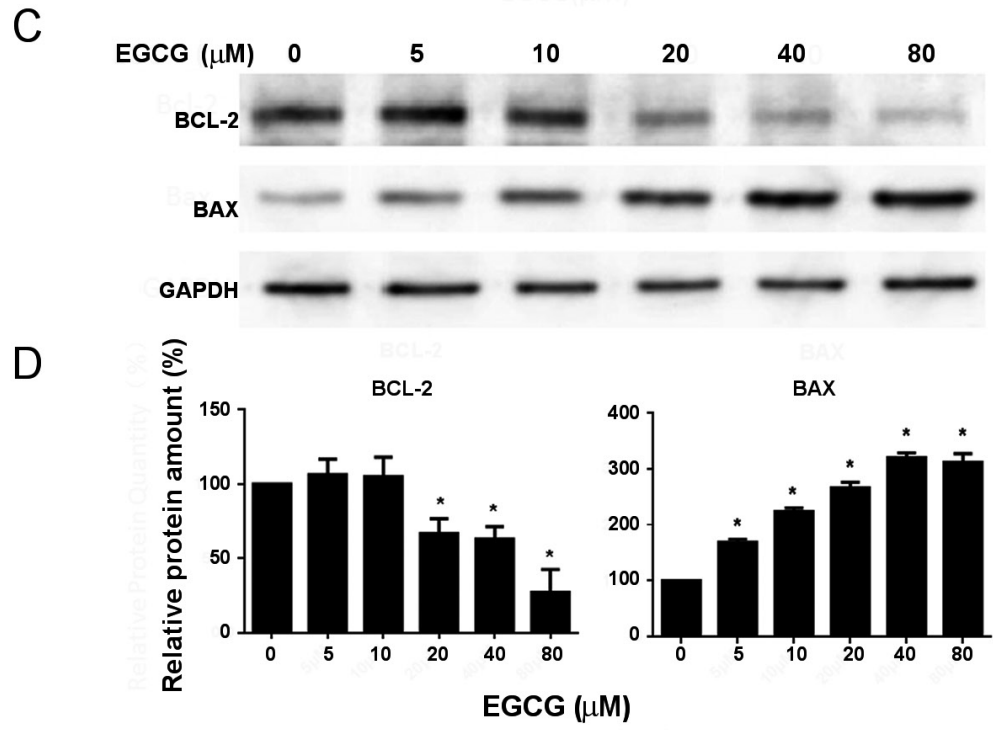

Figure 3. Effect of EGCG on the regulation of EFGR, Erk, Mek, Bcl-2 and Bax of SACC-83 cells.

Notes: (A) Representative Western blotting analysis of EFGR and Erk 1/2 (p-Erk 1/2), Mek (p-Mek) in SACC-83 cells. (B) Quantification of Western blotting band of EFGR and Erk 1/2 (p-Erk 1/2), Mek (p-Mek). (C) Representative Western blotting analysis of Bcl-2 and Bax in SACC-83 cells. (D) Quantification of Western blotting band of Bcl-2 and Bax. SACC-83 cells were treated for $48 \mathrm{~h}$ with EGCG (0-80 $\mu \mathrm{M})$ and equal amounts of total protein were immunoblotted with anti-EGFR, anti-Erk 1/2, anti-p-Erk 1/2, anti-Mek, anti-p-Mek, anti-Bcl-2 and anti-Bax antibodies. GAPDH was used as the internal control. Dates were obtained from 3 independent experiments and normalized with GAPDH. Symbol *illustrated there was difference between the drug group and control group $(\mathrm{P}<0.05)$, respectively. As the increase of EGCG $(0-80 \mu M)$, total amount of EGFR protein decreased $(P<0.05)$. And at the treatment of EGCG $(20-80 \mu \mathrm{M})$, the phosphorylation of Erk 1/2 and Mek were inhibited compared with control $(\mathrm{P}<0.05)$. Received the treatment of EGCG $(20-80 \mu \mathrm{M})$, the Bcl-2 was inhibited compared with control $(\mathrm{P}<0.05)$. And as the increase of EGCG $(0-80 \mu \mathrm{M}), \mathrm{Bax}$ was upregulated $(\mathrm{P}<0.05)$. 
determine the multiple therapeutic targets other than single target. The pathogenesis of ACC is unclear, until now relatively few genetic alterations critical to the ACC development have been recognized. The MYB-NFIB translocation has recently been identified in ACC and may play an important role in the development of ACC $[33,34]$, and the MYB-NFIB translocation may evolve as another potential therapeutic targets in the future [35]. Report showed that targeted therapies directed against the EGFR and PTEN proteins or their constitutive pathways may be valuable in the treatment of ACC [36].

EGCG, the most major constituent of tea, has broad anticancer properties, including those for cancers of the skin, lung, oral cavity, stomach, small intestine and so on [37]. Studies have shown that the mechanisms of its anticancer properties are very complex, such as enhancement of apoptosis, suppression of cell proliferation, inhibition of angiogenesis and so on [38-40]. Additionally, it is likely that multiple molecular mechanisms, rather than a single target, are involved [41]. However, there is no relevant evidence for its efficacy in the treatment of ACC. Thus, we hypothesized that EGCG may has a good anti-tumor activity in ACC.

In the present study, it was shown that EGCG had an effective anti-tumor activity on SACC-83 cell lines. According to the MTS and flow cytometry, EGCG was able to inhibit proliferation and promote apoptosis of ACC cells, as was confirmed in multiple cell lines, such as renal cell carcinoma (RCC) cells and human villous trophoblasts (HVT) [42, 43]. Uncontrolled growth is a necessary step for the development of all cancers. EGFR plays critical roles in ligand-activated signaling pathways that regulate cell proliferation and death [44], and involves in the development of many malignant tumors, such as ACC, colon cancer and non-small cell lung cancer [45-47]. It was shown that EGFR was overexpressed in the ACC and owned with biologic aggressiveness and poor prognosis of malignant character [48]. Activating mutations and overexpression of receptor tyrosine kinases just like EGFR represent an important source of therapeutic resistance in salivary gland adenoid cystic carcinoma [45]. So it was deduced that EGFR played an essential role in anti-tumor of the ACC treated by EGCG. Previous studies revealed that MAPK signaling is a key pathway of cellular proliferation and apoptosis regulation, and a major downstream signaling route of the MAPK signaling is via the Ras-Raf-Erk kinase pathway and at last regulates the cell proliferation, survival, apoptosis and transformation [49]. In the present study, it was demonstrated that the expression of EGFR was reduced, phosphorylation of Erk and Mek was inhibited. Furthermore, it was also found that mRNA level of P90 RSK was suppressed and RSK was a downstream mediator of the MAPK pathway that regulates proliferation and apoptosis in a variety of cancer cell lines [50]. RSK phosphorylates multiple signaling effectors to play an essential role in a number of cellular functions, including regulation of gene expression by phosphorylation of transcriptional regulators, including c-Fos and CREB; regulation of cell cycle by phosphorylating and inhibiting Myt1 [51]; and regulation

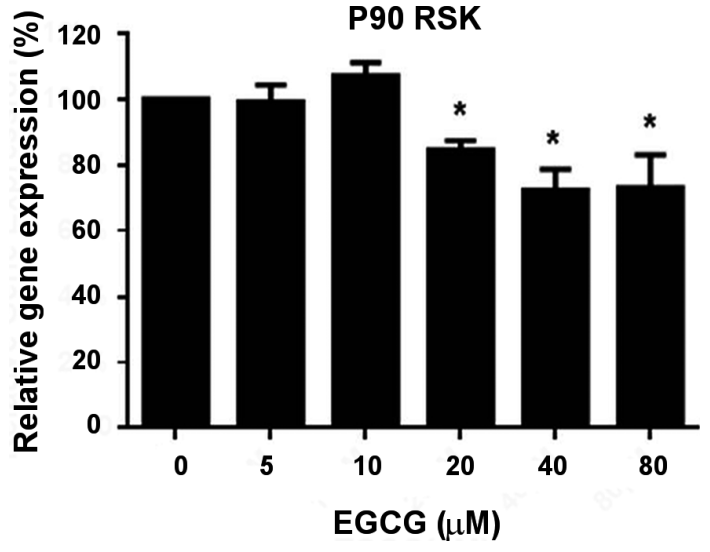

Figure 4. Relative P90 RSK gene expression level of SACC-83 after cells were treated with EGCG $(0-80 \mu \mathrm{M})$ for $48 \mathrm{~h}$.

Notes: P90 RSK gene expression level was detected by Quantitative RT-PCR. GAPDH was used to normalize the expression levels. Relative mRNA expression was calculated using the $\Delta \Delta \mathrm{Ct}$ method. Genes with a fold change of $\leq-1.25$ or $\geq 1.25$ and $P<0.05$ were considered statistically significant. Significant difference compared with control (EGCG 0) can be found at ${ }^{\star}(\mathrm{P}<0.05)$, EGCG $(20-80 \mu \mathrm{M})$ distinctively reduced $\mathrm{mRNA}$ levels of P90 RSK gene.

of cell survival by phosphorylating Bad, Bim, and DAPK to protect cells from apoptosis [52]. So it may concluded EGCG inhibits proliferation and promotes apoptosis of SACC-83 cells in vitro via an EGFR dependent signaling transduction mechanism and regulates SACC tumor cell activity through the MAPK mediated pathway.

Accumulating evidence indicates that the anti-tumor effect of EGCG is also depending on promoting cell apoptosis. There are two major signaling pathways induce apoptotic cell death, the mitochondrial (the intrinsic) pathway and the death receptor (the extrinsic) pathway [52]. Bcl-2 family is divided into two subgroups according to their functions: the anti-apoptotic Bcl-2 family members and the pro-apoptotic members [53]. $\mathrm{Bcl}-2$ and Bax are the most representative anti-apoptotic and pro-apoptotic protein in the $\mathrm{Bcl}-2$ family while $\mathrm{Bax}$ is the main regulator of Bcl-2 activity [53]. Studies have shown that EGCG has the effect to downregulate the expression of $\mathrm{Bcl}-2$ protein and to upregulate Bax. In OSCC, compared with oral epithelium, there is a decreased Bcl-2 expression by EGCG [27]. In $B$ lymphoma cells, EGCG upregulated the protein expression of Fas and Bax while downregulating Bcl-2 to induce B lymphoma cells apoptosis [54]. Indirectly inducing up-regulation of pro-apoptotic signals or directly inhibiting the activity of anti-apoptotic proteins are two strategies that may target the evasion of cancer cells for treatment [55]. According the results of our research (Figure 3), we conclude that EGCG initiates the mitochondrial pathway to induce apoptosis of SACC-83 cells. Compared to cause necrosis of tumor cells, inducing the apoptosis of tumor cells can promote tumor ablation or even elimination, at the same time reduce the inflammatory reaction and other side effects of surrounding normal tissues 
[56]. Therefore, the drugs which induce apoptosis of tumor cells are better than chemotherapeutic drugs which cause cell necrosis. According to the strategy of inducing apoptosis for cancer therapy, EGCG which can upregulate pro-apoptotic protein and inhibit the expression of anti-apoptotic proteins would be a potential therapeutic drug for the patients with SACC tumors.

In conclusion, the present study proposes that EGCG would exert anticancer effects on SACC- 83 cells and the evidences demonstrate that EGCG is able to inhibit growth and induce apoptosis of SACC-83 cells by reducing expression of EGFR, which can active EGFR/Erk/P90 RSK pathway, and initiating mitochondria apoptosis pathway. It also suggests EGCG may be a potential therapeutic or adjuvant strategy for the treatment of patients with SACC tumors. However, it is unclear how EGCG acts on these pathways, and whether these signaling pathways relate to other beneficial effects of EGCG.

Acknowledgments: This project was supported by grants from The Zhejiang Provincial Natural Science Foundation of China (LY14H140001, LY14H140003).

\section{References}

[1] BRADLEY PJ. Adenoid cystic carcinoma of the head and neck: a review. Curr Opin Otolaryngol Head Neck Surg 2004; 12: 127-132. https://doi.org/10.1097/00020840-200404000-00013

[2] DANTAS AN, MORAIS EF, MACEDO RA, TINÔCO JM, MORAIS MDE L. Clinicopathological characteristics and perineural invasion in adenoid cystic carcinoma: a systematic review. Braz J Otorhinolaryngol 2015; 81:329-335. https://doi. org/10.1016/j.bjorl.2014.07.016

[3] ZHANG JL, PENG B, CHEN XM. Expressions of nuclear factor kappa B, inducible nitric oxide synthase, and vascular endothelial growth factor in adenoid cystic carcinoma of salivary glands: correlations with the angiogenesis and clinical outcome. Clin Cancer Res 2005; 11: 7334-7343. https://doi. org/10.1158/1078-0432.CCR-05-0241

[4] JU J, LI Y, CHAI J, MA C, NI Q et al. The role of perineural invasion on head and neck adenoid cystic carcinoma prognosis: a systematic review and meta-analysis. Oral Surg Oral Med Oral Pathol Oral Radiol 2016; 122: 691-701. https://doi. org/10.1016/j.oooo.2016.08.008

[5] KOKEMUELLER H, ECKARDT A, BRACHVOGE P, HAUSAMEN JE. Adenoid cystic carcinoma of the head and neck-a 20 year's experience. Int J Oral Maxillofac Surg 2004; 33: 25-31. https://doi.org/10.1054/ijom.2003.0448

[6] CHEN AM, BUCCI MK, WEINBERG V, GARCIA J, QUIVEY $\mathrm{JM}$ et al. Adenoid cystic carcinoma of the head and neck treated by surgery with or without postoperative radiation therapy: prognostic features of recurrence. Int J Radiat Oncol Biol Phys 2006; 66: 152-159. https://doi.org/10.1016/j. ijrobp.2006.04.014

[7] BRADLEY PJ, FERRIS RL. Surgery for malignant sublingual and minor salivary gland neoplasms. Adv Otorhinolaryngol 2016; 78: 113-119. https://doi.org/10.1159/000442131
[8] MARCINOW A, OZER E, TEKNOS T, WEI L, HURTUK A et al. Clinicopathologic predictors of recurrence and overall survival in adenoid cystic carcinoma of the head and neck: a single institutional experience at a tertiary care center. Head Neck 2014; 36: 1705-1711. https://doi.org/10.1002/hed.23523

[9] CHOI E J, BAE S M, AHN W S. Antiproliferative effects of quercetin through cell cycle arrest and apoptosis in human breast cancer MDA-MB-453 cells. Arch Pharm Res 2008; 31: 1281-1285. https://doi.org/10.1007/s12272-001-2107-0

[10] UMEDA D, YANO S, YAMADA K, TACHIBANA H. Green tea polyphenol epigallocatechin-3-gallate signaling pathway through 67-kDa laminin receptor. J Biol Chem 2008; 283: 3050-3058. https://doi.org/10.1074/jbc.M707892200

[11] LEE UL, CHOI SW. The chemopreventive properties and therapeutic modulation of green tea polyphenols in oral squamous cell carcinoma. ISRN Oncol 2011; 2011: 403707.

[12] BRAICU C, LADOMERY MR, CHEDEA VS, IRIMIE A, BERINDAN-NEAGOE I. The relationship between the structure and biological actions of green tea catechins. Food Chem 2013; 141: 3282-3289. https://doi.org/10.1016/j.foodchem.2013.05.122

[13] SHIMIZU M, DEGUCHI A, JOE AK, MCKOY JF, MORIWAKI H ET AL. EGCG inhibits activation of HER3 and expression of cyclooxygenase- 2 in human colon cancer cells. J Exp Ther Oncol 2005; 5: 69-78.

[14] MASUDA M, SUZUI M, WEINSTEIN I B. Effects of epigallocatechin-3-gallate on growth, epidermal growth factor receptor signaling pathways, gene expression, and chemosensitivity in human head and neck squamous cell carcinoma cell lines. Clin Cancer Res 2001; 7: 4220-4229.

[15] MASUDA M, SUZUI M, LIM J T E, DEGUCHI A, SOH JW et al. Epigallocatechin-3-gallate decreases VEGF production in head and neck and breast carcinoma cells by inhibiting EGFR-related pathways of signal transduction. J Exp Ther Oncol 2002; 2: 350-359. https://doi.org/10.1046/j.13594117.2002.01062.x

[16] SHIMIZU M, SHIRAKAMI Y, SAKAI H, TATEBE H, NAKAGAWA T et al. EGCG inhibits activation of the insulin-like growth factor (IGF)/IGF-1 receptor axis in human hepatocellular carcinoma cells. Cancer Lett 2008; 262: 10-18. https:// doi.org/10.1016/j.canlet.2007.11.026

[17] YANG C S, MALIAKAL P, MENG X. Inhibition of Carcinogenesis by Tea. Annu Rev Pharmacol Toxicol 2002; 42: 25-54. https://doi.org/10.1146/annurev.pharmtox.42.082101.154309

[18] VALCIC S, MUDERS A, JACOBSEN NE, LIEBLER DC, TIMMERMANN BN. Antioxidant chemistry of green tea catechins. Identification of products of the reaction of (-)-epigallocatechin gallate with peroxyl radicals[J]. Chem Res Toxicol 1999; 12: 382-386. https://doi.org/10.1021/tx990003t

[19] RODRIGUEZ SK, GUO W, LIU L, BAND MA, PAULSON EK et al. Green tea catechin, epigallocatechin-3-gallate, inhibits vascular endothelial growth factor angiogenic signaling by disrupting the formation of a receptor complex. Int J Cancer 2006; 118: 1635-1644. https://doi.org/10.1002/ijc.21545

[20] ZHANG X, ZHANG H, TIGHIOUART M, LEE JE, SHIN HJ et al. Synergistic inhibition of head and neck tumor growth by green tea (-)-epigallocatechin-3-gallate and EGFR tyrosine 
kinase inhibitor. Int J Cancer 2008;123: 1005-1014. https:// doi.org/10.1002/ijc. 23585

[21] SAH JF, BALASUBRAMANIAN S, ECKERT RL, RORKE EA. Epigallocatechin-3-gallate inhibits epidermal growth factor receptor signaling pathway. Evidence for direct inhibition of ERK1/2 and AKT kinases. J Biol Chem 2004; 279: 12755-12762. https://doi.org/10.1074/jbc.M312333200

[22] KOH Y W, CHOI E C, KANG S U, HWANG HS, LEE MH et al. Green tea (-)-epigallocatechin-3-gallate inhibits HGFinduced progression in oral cavity cancer through suppression of HGF/c-Met. J Nutr Biochem 2011; 22: 1074-1083. https:// doi.org/10.1016/j.jnutbio.2010.09.005

[23] HWANG J T, HA J, PARK I J, LEE SK, BAIK HW et al. Apoptotic effect of EGCG in HT-29 colon cancer cells via AMPK signal pathway. Cancer Lett 2007; 247: 115-121. https://doi. org/10.1016/j.canlet.2006.03.030

[24] SHARMA C, NUSRI QEL-A, BEGUM S, JAVED E, RIZVI TA et al. (-)-Epigallocatechin-3-gallate induces apoptosis and inhibits invasion and migration of human cervical cancer cells. Asian Pac J Cancer Prev 2012; 13: 4815-4822. https:// doi.org/10.7314/APJCP.2012.13.9.4815

[25] ZHANG Y, OWUSU L, DUAN W, JIANG T, ZANG S ET AL. Anti-metastatic and differential effects on protein expression of epigallocatechin-3-gallate in HCCLM6 hepatocellular carcinoma cells. Int J Mol Med 2013; 32: 959-964.

[26] GRANADO-SERRANO AB, MARTIN MA, BRAVO L, GOYA L, RAMOS S. Quercetin induces apoptosis via caspase activation, regulation of $\mathrm{Bcl}-2$, and inhibition of PI-3-kinase/ Akt and ERK pathways in a human hepatoma cell line (HepG2). J Nutr 2006; 136: 2715-2721.

[27] IRIMIE AI, BRAICU C, ZANOAGA O, PILECZKI V, GHERMAN C et al. Epigallocatechin-3-gallate suppresses cell proliferation and promotes apoptosis and autophagy in oral cancer SSC-4 cells. Onco Targets Ther 2015; 8: 461-470.

[28] DODD RL, SLEVIN NJ. Salivary gland adenoid cystic carcinoma: a review of chemotherapy and molecular therapies. Oral Oncol 2006; 42: 759-769. https://doi.org/10.1016/j. oraloncology.2006.01.001

[29] BRADLEY, P.J. Adenoid cystic carcinoma of the head and neck: a review. Curr Opin Otolaryngol Head Neck Surg 2004; 12 : 127-132. https://doi.org/10.1097/00020840-200404000-00013

[30] BHAYANI MK, YENER M, EL-NAGGAR A, GARDEN A, HANNA EY et al. Prognosis and risk factors for early-stage adenoid cystic carcinoma of the major salivary glands. Cancer 2012; 118: 2872-2878. https://doi.org/10.1002/cncr.26549

[31] GREENPLATE AR, JOHNSON DB, FERRELL PB JR, IRISH JM. Systems immune monitoring in cancer therapy. Eur J Cancer2016; 61:77-84. https://doi.org/10.1016/j.ejca.2016.03.085

[32] SEN M, PRESTWICH R. Chemotherapy and Targeted Therapy. Adv Otorhinolaryngol 2016; 78: 148-156. https:// doi.org/10.1159/000442135

[33] WYSOCKI PT, IZUMCHENKO E, MEIR J, HA PK, SIDRANSKY D et al. Adenoid cystic carcinoma: emerging role of translocations and gene fusions. Oncotarget 2016; 7: 66239-66254. https://doi.org/10.18632/oncotarget.11288

[34] BHAIJEE F, PEPPER DJ, PITMAN KT, BELL D. New developments in the molecular pathogenesis of head and neck tumors: a review of tumor-specific fusion oncogenes in mucoepidermoid carcinoma, adenoid cystic carcinoma, and NUT midline carcinoma. Ann Diagn Pathol 2011; 15: 69-77. https://doi. org/10.1016/j.anndiagpath.2010.12.001

[35] LEWIS AG, TONG T, MAGHAMI E. Diagnosis and Management of Malignant Salivary Gland Tumors of the Parotid Gland. Otolaryngol Clin North Am 2016; 49: 343-380. https:// doi.org/10.1016/j.otc.2015.11.001

[36] SIMPER NB, JONES CL, MACLENNAN GT, MONTIRONI $\mathrm{R}$, WILLIAMSON SR et al. Basal cell carcinoma of the prostate is an aggressive tumor with frequent loss of PTEN expression and overexpression of EGFR. Hum Pathol 2015; 46: 805-812. https://doi.org/10.1016/j.humpath.2015.02.004

[37] YANG CS, WANG H, LI GX, YANG Z, GUAN F et al. Cancer prevention by tea: Evidence from laboratory studies. Pharmacol Res 2011; 64: 113-122. https://doi.org/10.1016/j. phrs.2011.03.001

[38] JU J, LU G, LAMBERT JD, YANG CS. Inhibition of carcinogenesis by tea constituents. Semin Cancer Biol 2007; 17: 395-402. https://doi.org/10.1016/j.semcancer.2007.06.013

[39] CHAKRAWARTI L, AGRAWAL R, DANG S, GUPTA S, GABRANI R. Therapeutic effects of EGCG: a patent review. Expert Opin Ther Pat 2016; 26: 907-916. https://doi.org/10. 1080/13543776.2016.1203419

[40] SINGH BN, SHANKAR S, SRIVASTAVA RK. Green tea catechin epigallocatechin-3-gallate (EGCG): mechanisms, perspectives and clinical applications. Biochem Pharmacol 2011; 82: 1807-1821. https://doi.org/10.1016/j. bcp.2011.07.093

[41] YANG CS, WANG X, LU G, PICINICH SC. Cancer prevention by tea: animal studies, molecular mechanisms and human relevance. Nat Rev Cancer 2009; 9: 429-439. https:// doi.org/10.1038/nrc2641

[42] CHEN SJ, YAO XD, PENG BO, XU YF, WANG GC et al. Epigallocatechin-3-gallate inhibits migration and invasion of human renal carcinoma cells by downregulating matrix metalloproteinase-2 and matrix metalloproteinase-9. Exp Ther Med 2016; 11: 1243-1248. https://doi.org/10.3892/etm.2016.3050

[43] SHIH LJ, CHEN TF, LIN CK, LIU HS, KAO YH. Green tea (-)-epigallocatechin gallate inhibits the growth of human villous trophoblasts via the ERK, p38, AMP-activated protein kinase, and protein kinase B pathways. Am J Physiol Cell Physiol 2016; 311: C308-21. https://doi.org/10.1152/ ajpcell.00003.2016

[44] RUSNAK DW, ALLIGOOD KJ, MULLIN RJ, SPEHAR GM, ARENAS-ELLIOTT C et al. Assessment of epidermal growth factor receptor (EGFR, ErbB1) and HER2 (ErbB2) protein expression levels and response to lapatinib (Tykerb, GW572016) in an expanded panel of human normal and tumour cell lines. Cell Prolif 2007; 40: 580-594. https://doi.org/10.1111/j.13652184.2007.00455.x

[45] HUANG Y, YU T, FU X, CHEN J, LIU Y et al. EGFR inhibition prevents in vitro tumor growth of salivary adenoid cystic carcinoma. BMC Cell Biol 2013; 14: 13. https://doi. org/10.1186/1471-2121-14-13

[46] SHIMIZU M, DEGUCHI A, LIM JT, MORIWAKI H, KOPELOVICH L et al.(-)-Epigallocatechin gallate and 
polyphenon $\mathrm{E}$ inhibit growth and activation of the epidermal growth factor receptor and human epidermal growth factor receptor-2 signaling pathways in human colon cancer cells. Clin Cancer Res 2005; 11: 2735-2746. https://doi. org/10.1158/1078-0432.CCR-04-2014

[47] NORMANNO N, DENIS MG, THRESS KS, RATCLIFFE M, RECK $M$. Guide to detecting epidermal growth factor receptor (EGFR) mutations in ctDNA of patients with advanced non-small-cell lung cancer. Oncotarget 2016; [Epub ahead of print]. https://doi.org/10.18632/oncotarget.13915

[48] AGULNIK M, COHEN EW, COHEN RB, CHEN EX, VOKES EE et al. Phase II study of lapatinib in recurrent or metastatic epidermal growth factor receptor and/or erbB2 expressing adenoid cystic carcinoma and non adenoid cystic carcinoma malignant tumors of the salivary glands. J Clin Oncol 2007; 25: 3978-3984. https://doi.org/10.1200/JCO.2007.11.8612

[49] MENDELSOHN J, BASELGA J. Status of epidermal growth factor receptor antagonists in the biology and treatment of cancer. J Clin Oncol 2003; 21: 2787-2799. https://doi. org/10.1200/JCO.2003.01.504

[50] EISINGER-MATHASON TS, ANDRADE J, LANNIGAN DA. RSK in tumorigenesis: connections to steroid signaling. Steroids 2010; 75: 191-202. https://doi.org/10.1016/j. steroids.2009.12.010
[51] SULZMAIER FJ, RAMOS JW. RSK isoforms in cancer cell invasion and metastasis. Cancer Res 2013; 73: 6099-6105. https://doi.org/10.1158/0008-5472.CAN-13-1087

[52] GREEN DR, LLAMBI F. Cell Death Signaling. Cold Spring Harb Perspect Biol 2015; 7: a006080. https://doi.org/10.1101/ cshperspect.a006080

[53] TISCHNER D, WOESS C, OTTINA E, VILLUNGER A. Bcl-2-regulated cell death signalling in the prevention of autoimmunity. Cell Death Dis 2010; 1: e48. https://doi. org/10.1038/cddis.2010.27

[54] WANG J, XIE Y, FENG Y, ZHANG L, HUANG X et al. (-)-Epigallocatechingallate induces apoptosis in B lymphoma cells via caspase-dependent pathway and Bcl-2 family protein modulation. Int J Oncol 2015; 46: 1507-1515. https://doi. org/10.3892/ijo.2015.2869

[55] SAROSIEK KA, LETAI A. Directly targeting the mitochondrial pathway of apoptosis for cancer therapy with BH3 mimetics: recent successes, current challenges and future promise. FEBS J 2016; 283: 3523-3533. https://doi. org/10.1111/febs.13714

[56] BEEBE SJ, FOX PM, REC LJ, WILLIS EL, SCHOENBACH KH. Nanosecond, high-intensity pulsed electric fields induce apoptosis in human cells. FASEB J 2003; 17: 1493-1495. https://doi.org/10.1096/fj.02-0859fje 